\title{
Natural and technogenic components of megalopolis magnetic field
}

\author{
(c) M. Orlyuk, A. Romenets, I. Orliuk, 2016
}

Institute of Geophysics, National Academy of Sciences of Ukraine,
Kiev, Ukraine

Received November 5, 2015

Presented by the Editorial Board Member V. I. Starostenko

\begin{abstract}
Вплив магнітних бур на людину стає останнім часом все цікавішим. У статті викладено результати досліджень змінного магнітного поля техногенного походження в різних районах мегаполісу і підземному транспорті на прикладі м. Київ. Виміри проведені в п'яти пунктах у різних районах міста, а також у метро в обох напрямках руху поїзда. Отримана інформація показує загальну ситуацію з магнітним шумом у густонаселених містах. Як бюджетний варіант для вимірювань в метро використаний смартфон з вбудованим магнітометром.
\end{abstract}

Ключові слова: природне геомагнітне поле, техногенне магнітне поле, магнітний шум.

Introduction. At the present time there are a lot of data about the influence of constant and wide frequency range magnetic field variations on live organisms and human activity [Travkin, 1971; ICNIRP ..., 1998; Pavlovich et al., 1991; Orlyuk, 2001; Physicical ..., 2003; Khramov et al., 2006; Serpov, 2007; Standart ..., 2008; Belokrinitskiy, 2009; Kulikov, Timofeeva, 2011; Medvedeva et al., 2011; Rozov et al., 2013; Gvishiani et al., 2013 and others]. In large megalopolises natural Earth's magnetic field is mostly complemented by technogenic component from different sources of constant and variable kind [Orlyuk, Romenets, 2004; Tyagunov, 2011; Romenets, Orliuk, 2013; Orlyuk et al., 2014]. In the minimal health norm of static magnetic field is a half of its background values in the residence territory [Physical ..., 2003]. The authors [Orlyuk, Romenets, 2005] suggested the value of its "ecological norm" nearby 35$55 \mu \mathrm{T}$. This article presents calculated and experimental data about Kiev and its surrounding area magnetic field of natural and technogenic origin.

1. Natural Earth's magnetic field. Spatiotemporal structure of the Earth's magnetic field induction $B$ is the sum of fields from different sources:

$$
B=B_{n}+\Delta B+\delta B
$$

where $B_{n}$ - normal (main) field of the Earth, gene- rated by the liquid core processes; $\Delta B$ - anomalous magnetic field (the lithosphere field), mainly caused by rocks magnetization, $\delta B$ - external field generated by solar and cosmic radiation actions, the Sun and near-Earth space magnetic fields.

Quasi-permanent geomagnetic field, which is the sum of main and lithosphere magnetic fields, sets the geomagnetic background where biosphere processes run and human lives. Afterwards, map of the magnetic induction module $B$ for Kiev region was developed.

Natural geomagnetic field varies within 50 100$50860 \mathrm{nT}$, increasing from southwest to northeast (Fig. 1).

Local spatial geomagnetic field inhomogeneity is mainly determined by its lithospheric component that varies within city from -200 to $500 \mathrm{nT}$.

The right riverside of the city (especially the old town) is mainly located in positive magnetic field areas with an intensity of $50-100 \mathrm{nT}$. The left riverside of the city is located in predominantly negative magnetic field areas (up to - $200 \mathrm{nT}$ ). On the left riverside only Rusanivka, Bereznyaky and partly Kharkivskyi, Bortnychi areas are characterized by low positive background near $50 \mathrm{nT}$.

Another feature of the field is grouping of incre- 
ased values in unique ovals, and grouping of low values - in linear zones of the north-west and northeast stretch. An interesting fact is some relation between building overgrowth and nature of the geomagnetic field [Orlyuk, Romenets, 2004; Rezinkina et al., 2009].

2. Technogenic magnetic field. Variable magnetic (electromagnetic) field of natural and tech- nogenic origin changes within $10^{-6} \mathrm{~Hz}-10 \mathrm{GHz}$ (Fig. 2, a).

Low frequency electric and magnetic alternating fields ("electrosmog"). This type of electromagnetic pollution is caused by home mains supply systems and by connected to them devices, by switches and lights, by high voltage lines, transformer stations and traction power.

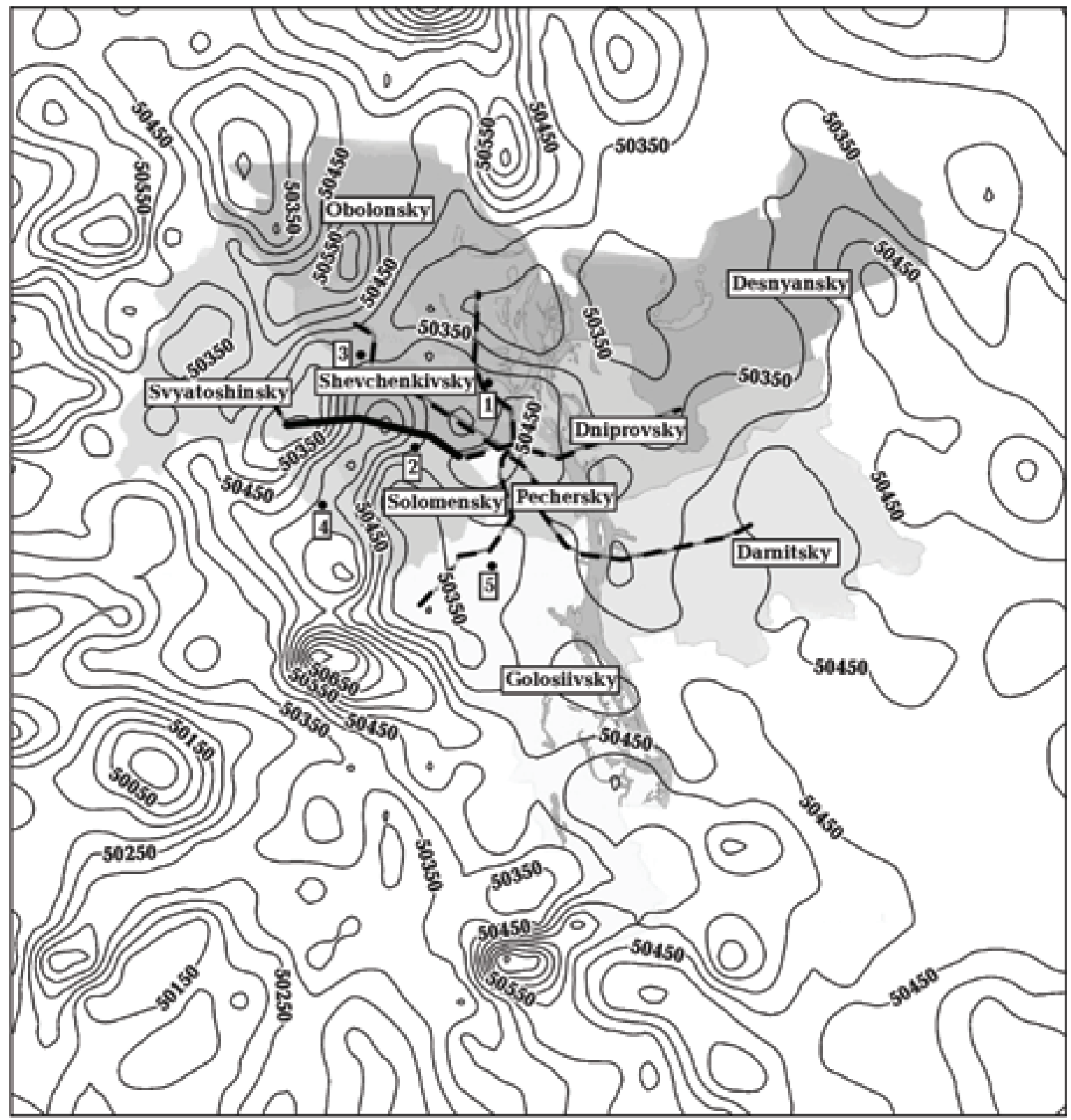

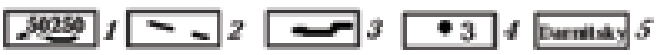

Fig. 1. Kiev map of scalar magnetic field $B$ (for Epoch 2013): 1 - isolines of induction $B, 2$ - metro route, 3 - metro stations observed, 4 - observation points, 5 - regions of Kiev. 


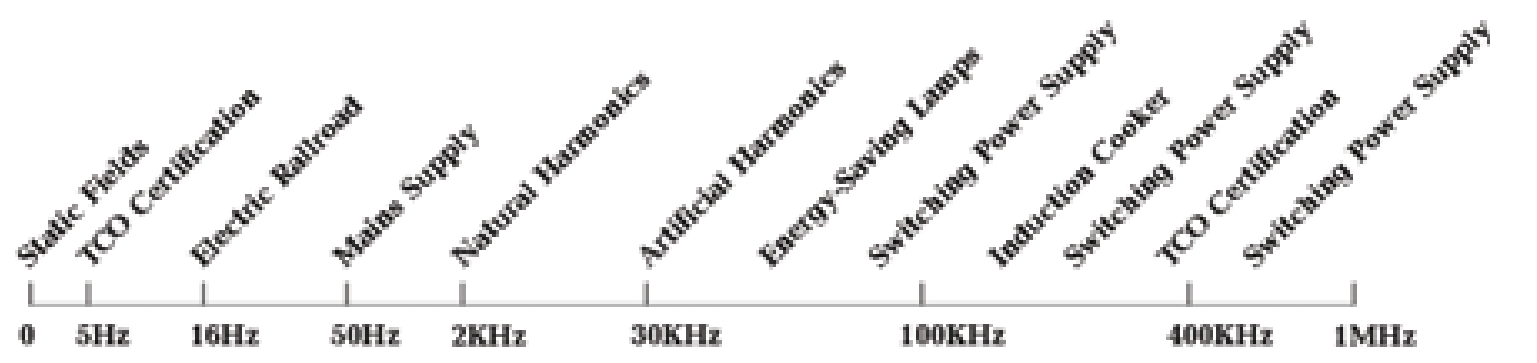

Low Frequencies

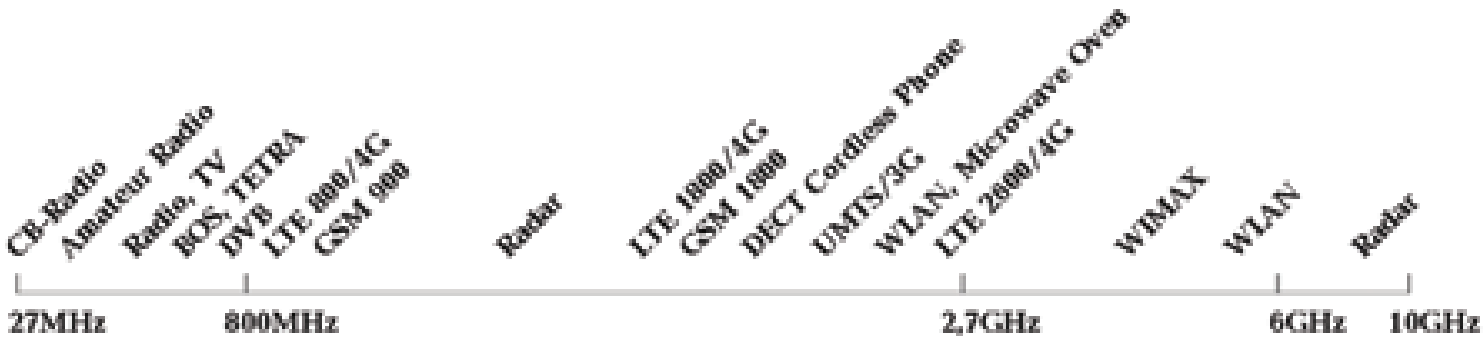

High Frequencles

Fig. 2. Low frequencies (a) and high frequencies (b).

High frequency radiation from $27 \mathrm{MHz}$ to $10 \mathrm{GHz}$ (Fig. 2, b), a range comprising frequencies from radio and TV (digital as well as analogue), TETRA (digital public safety networks), amateur radio, citizens band radio, microwave radio relay, mobile radio(GSM, GPRS, UMTS, LTE, CDMA, 3G, 4G), radar, DECT cordless telephones, Wi-Fi, WLAN, microwave ovens, WiMAX, and many more (www.gigahertz-solutions.de).

The greatest influence on technogenic electromagnetic noise at low frequencies $(0,5 \mathrm{~Hz}-400 \mathrm{KHz})$ is introduced by industrial frequency electric current users [Tyagunov, 2011, 2012]. Otherwise, technogenic sources at frequencies of $10^{-6}-1 \mathrm{~Hz}$ are the least explored and we explore it in our research.

The magnetic field at these frequencies may be associated with moving of ferromagnetic and electrical sources (cars, trams, trolleys, trains, electric trains and subway etc.), and some industrial processes which use DC equipment, etc.

Trolley movement (motors turning on and off) causes a change of the magnetic field with an amplitude of about $80 \mathrm{nT}$ at about $10 \mathrm{~m}$ distance from the road; $50-100 \mathrm{nT}$, caused by small magnetic mass- es movement (cars, vans, etc.); maximum amplitudes nearby $300-500 \mathrm{nT}$ are caused by large trucks and urban electric transport [Tyagunov, 2012].

It should be noticed that the anomalous magnetic field levels presented above are obtained at a distance of $10 \mathrm{~m}$ from the roadway and if measurements were made inside the vehicles, anomalous magnetic field level would be higher.

3. Equipment used. To study technological components of magnetic field magnetovariational station LEMI-008 was used [Korepanov et al., 1999], and for intensive sources a portable magnetometer built-in smartphone on Android operating system (with special software) was used (Table).

For high intensity variations registration, we have experimentally tested our device on the magnetic observatory (Earth's magnetic field variation) and by high intensity influence on sensor in office. Every experiment was duplicated by precision device (LEMI008). As a result of experimental measurements it was decided that YAMAHA YAS530 MS-3E high sensitivity 3-axis geomagnetic sensor is suitable for registration of high intensity anomalies. 
Results and discussions. Magnetic field variations measurements were made in 6 places, allocated more or less evenly within the territory of Kiev in industrial and utility rooms on the Palladina ave., Frunze, Harmatna, Bozhenka, Velyka Kiltseva and Vasyl'kivs'ka streets. The nature of magnetic field in the subway was also explored. According to theoretical and experimental studies, vertical component of the magnetic field $B z$ is the most sensitive to technogenic disturbance, increased values are explained by horizontal form currents from technogenic sources appearance on the Earth's surface [Tyagunov 2011; Romenets, Orliuk, 2013].

Magnetic field variations on observation points (OP) in comparison with geomagnetic observatory "Kiev" variations are shown on the graphs below (Fig. 3).

OP1 (Frunze Street27-29.11.2012). Vertical component of the magnetic field $\mathrm{Bz}$, has a saw-tooth kind of form, it indicates the presence of permanent mechanical or electromagnetic vibrations caused by the movement of cars and trams. The high-intensity magnetic field perturbations (300-500 nT) are caused, as it lately turned out, by the interference of slate production and more precisely by DC kilns working (Fig. 3, a).

OP2 (Garmatna street 14-16.12.2012). Significant deviations from the normal level of geomagnetic field in the "Kiev" observatory are observed. Three periods of it are allocated. During the daytime, when the $B$-component has a saw-tooth kind form, we are shown the presence of permanent mechanical or electromagnetic vibrations. Most likely, they are caused by the movement of vehicles and strong traffic on the Peremogy ave. On this basis there are high-intensity (300-400 nT) and high-fre- quency magnetic field perturbations, previously associated with interference (most likely with on/off processes) DC converters, heaters, etc. At night, the magnetic field has generally calm nature (Fig. $3, b$ ).

OP 3 (Bozhenka street, 09-11.01.2013). Significant deviations from the normal level of geomagnetic field in the "Kiev" observatory with the amplitude of up to $\sim 350 \mathrm{nT}$ are observed. Three periods of magnetic field perturbations are clearly distinguished. The graph of the $B z$ component of magnetic field has a saw-tooth kind sinusoidal form that indicates the presence of constant electromagnetic interference. Probably they are caused by the work of some equipment at the Paton Electric Welding Institute). The proximity of intensive traffic flows (Bozhenka str., Fedorova ave.) makes influence on the overall noise character also. As in previous cases, registered high-intensity $100-150 \mathrm{nT}$ magnetic field perturbations are associated with the DC converters, etc. At night, the magnetic field has generally calm nature (Fig. 3, c).

OP 4 (Velyka Kiltseva 1-04.02.2013). Variations of the magnetic field don't have any clear frequen$\mathrm{cy}$, so it is suggested that the nature of their occurrence is random (turning on/off of any appliances, repairs, etc.). During all the observation period aperiodicity single "bursts" of up to $30 \mathrm{nT}$ were registered. By their intensity they are not high and can be caused by reasons mentioned above. In the daytime, there are high-frequency magnetic field perturbations, but they are minor in intensity (10-15 nT). In general, excepting 2 periods of sporadic disturbances of magnetic field, one can say that magnetic field in this observation point is approximately normal (Fig. 3, d).

\section{Equipment used}

\begin{tabular}{|c|c|}
\hline $\begin{array}{l}\text { LEMI-008 } \\
\text { fluxgate magnetometer }\end{array}$ & $\begin{array}{l}\text { YAMAHA YAS530 MS-3E high sensitivity 3-axis } \\
\text { geomagnetic sensor }\end{array}$ \\
\hline $\begin{array}{c}\text { Measurable magnetic field range: } \\
\text { Range I }-100000 \mathrm{nT} \\
\text { Range II }-3200 \mathrm{nT} \\
\text { Resolution: } \\
\text { Range I }-10 \mathrm{nT} \\
\text { Range II }-0.1 \mathrm{nT} \\
\text { Bandwidth of analog output DC }-1 \mathrm{~Hz} \\
\text { Smooth offset ranging band by each axis } \pm 1000 \mathrm{nT} \\
\text { Time of samples averaging, } \mathrm{s}: 1,2,5,10,60 \\
\text { Operating temperature range }-5 \text { to }+40^{\circ} \mathrm{C}\end{array}$ & $\begin{array}{l}\text { Measurable magnetic field range } \pm 800 \mu \mathrm{T} \\
\text { Magnetic field sensitivity }(X, Y) 0.15 \mu \mathrm{T} / \text { count } \\
\text { Magnetic field sensitivity }(Z) 0.3 \mu \mathrm{T} / \text { count } \\
\text { Acquisition time }-1.5 \mathrm{~ms} \\
\text { Operating temperature range }-40 \text { to }+95^{\circ} \mathrm{C}\end{array}$ \\
\hline
\end{tabular}




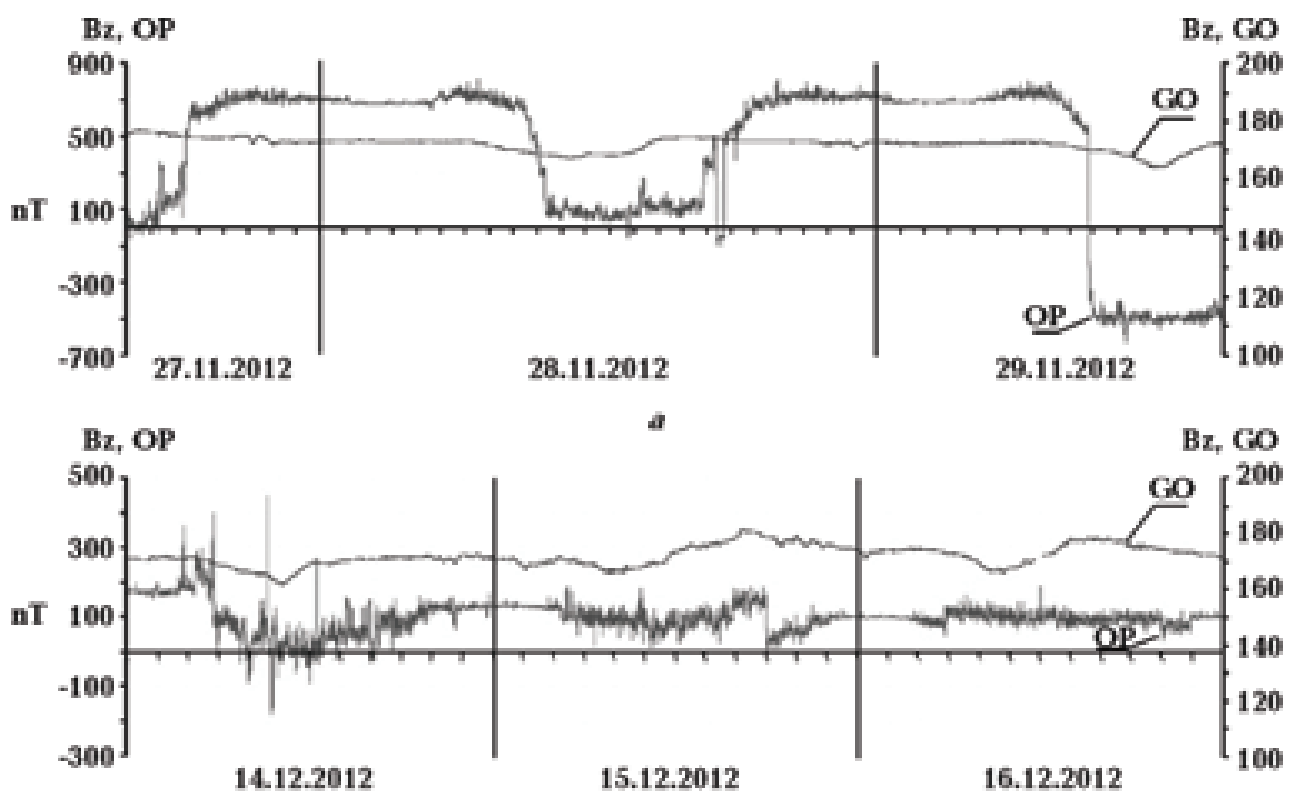

$b$

$\mathrm{Bz}, \mathrm{GO}$

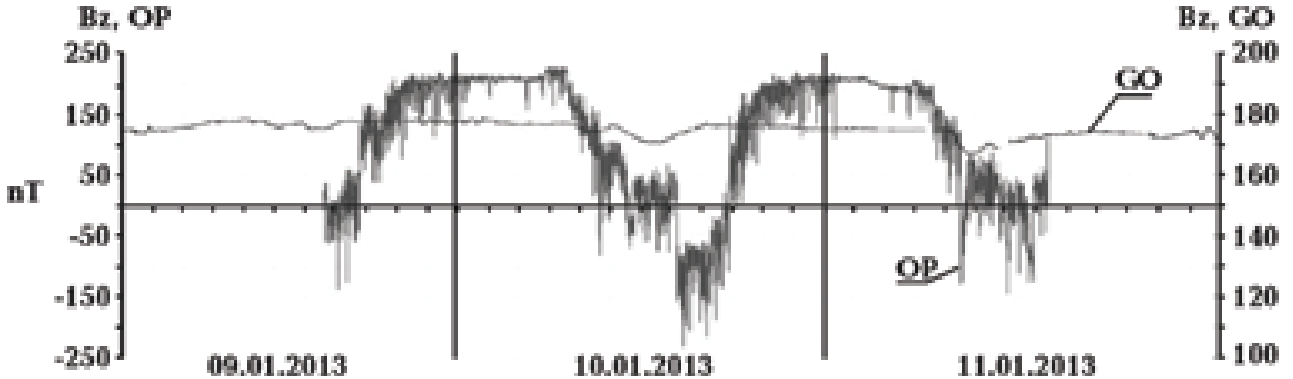

09.01 .2013

10.01 .2013

11.01 .2013

$\mathrm{Bz}, \mathrm{GO}$

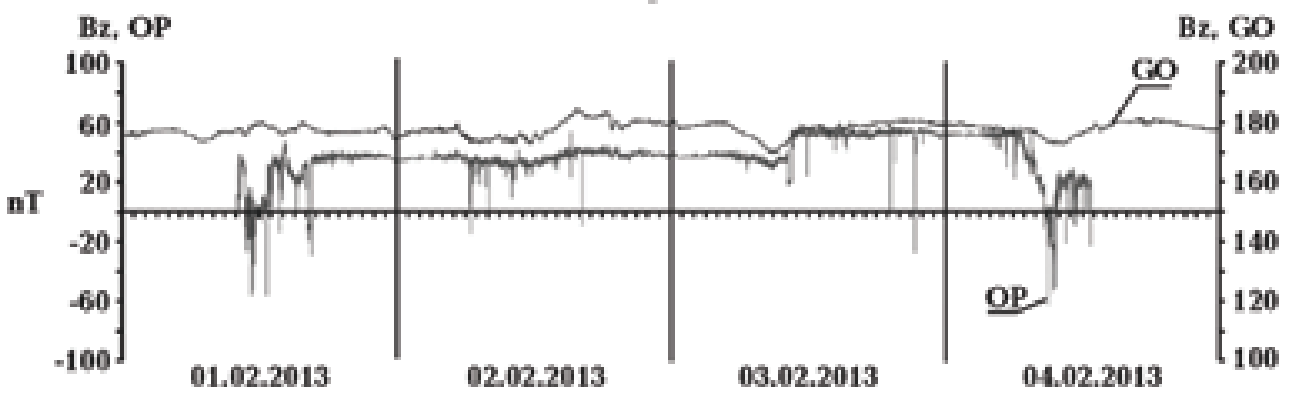

01.02 .2013

$\boldsymbol{d}$
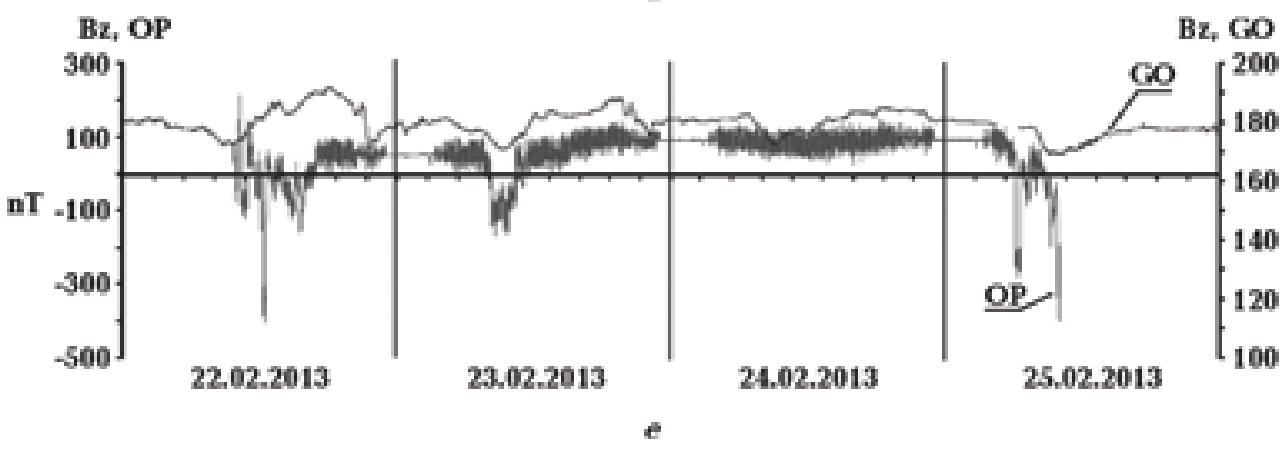

Fig. 3. Results of measurements in observation point (OP): Frunze Street (a); Garmatna street (b); Bozhenka street (c); Velyka Kiltseva (d); Vasyl'kivs'ka street (e). GO - "Kiev" geomagnetic observatory vertical component $B z$ variation, OP - observation point vertical component $B z$ variation. 
OP 5 (Vasyl'kivs'ka street, 22-25.02.2013) in the "Kyianka" factory basement. The highest level variations of technogenic origin were fixed at 250$600 \mathrm{nT}$. It should be noticed that the abnormal value during 23-24 of February (weekend) is slightly lower than the 22 and 25 of February. Noticed deviations of magnetic field level have clear periodicity and it suggests their regular occurrence (most likely it is the effect from the subway). At night, the magnetic field has a quiet character and is not significantly different from the "Kiev" magnetic observatory data. The sawtooth kind high-intensity magnetic field perturbations to $150 \mathrm{nT}$ are also recorded in the daytime and it recognizes the "saturation" of these periods by various magnetic field noises (Fig. 3, e).

Magnetic variations registration was conducted on the observation points in November-December 2012-January-February 2013 for 2-3 days in each of them. As it is shown in Fig. 3, within Kiev magnetic field is significantly different from the results of magnetic observatory data obtained $45 \mathrm{~km}$ from Kiev.

By experimental measurement results [Orlyuk, Romenets, 2004; Rozov et al., 2013] at Kiev underground metro stations, magnetic field induction changes within $25-40 \mu \mathrm{T}$ (it is less in 1.5-2 times than on surface).

Measurements of geomagnetic field variations in the subway were made on the interval between Beresteyska and Akademmistechko metro stations (Fig. 4). After processing the digital data it can be clearly seen all increased periods of magnetic induction.

Peaks and periods of magnetic field increasing in the range of $40-350 \mu \mathrm{T}$ at subway stations are seen on the graph. It is noticed that induction is primarily caused by motors located in the center of each carriage, and it shortly increases during the train acceleration. Besides of train motors, underground utilities, construction of subway tunnels and the ground-based infrastructure also produces magnetic noise. You can see from the graph that in the Svyatoshyn zone a busy junction is located.

Subway measurements of geomagnetic field variations were conducted in the interval Universitet and Zhytomyrska metro stations and in the reverse direction (Fig. 5). After processing the digital data all the periods of magnetic induction increase are shown. Between Beresteyska and Shulyavska stations we can see the anomaly of railway station. We can see that in the intervals such as UniversitetVokzalna and Svyatoshyn-Zhytomyrska the data on both graphs differ, it is explained by the inclination of the route (when a train goes up it uses a motor and when it goes down the motor is turned off).

Conclusions. For the territory of Kiev natural geomagnetic field varies within $50100-50860 \mathrm{nT}$, increasing from southwest to northeast.

Technological different-period variations that are registered have amplitudes from tens to hundreds of nanoteslas and significantly differ from magnetic field variations on "Kiev" magnetic observatory. The highest values of induction $B$ (up to $100-350 \mu \mathrm{T}$ ) are registered in the subway, while train accelerates and slows down; technogenic variation sources have in most cases electrical and ferromagnetic origin, and are associated with turning on/off and working of direct current sources, movement of electric transport including the subway, and mechanical movement of different kinds of vehicles.

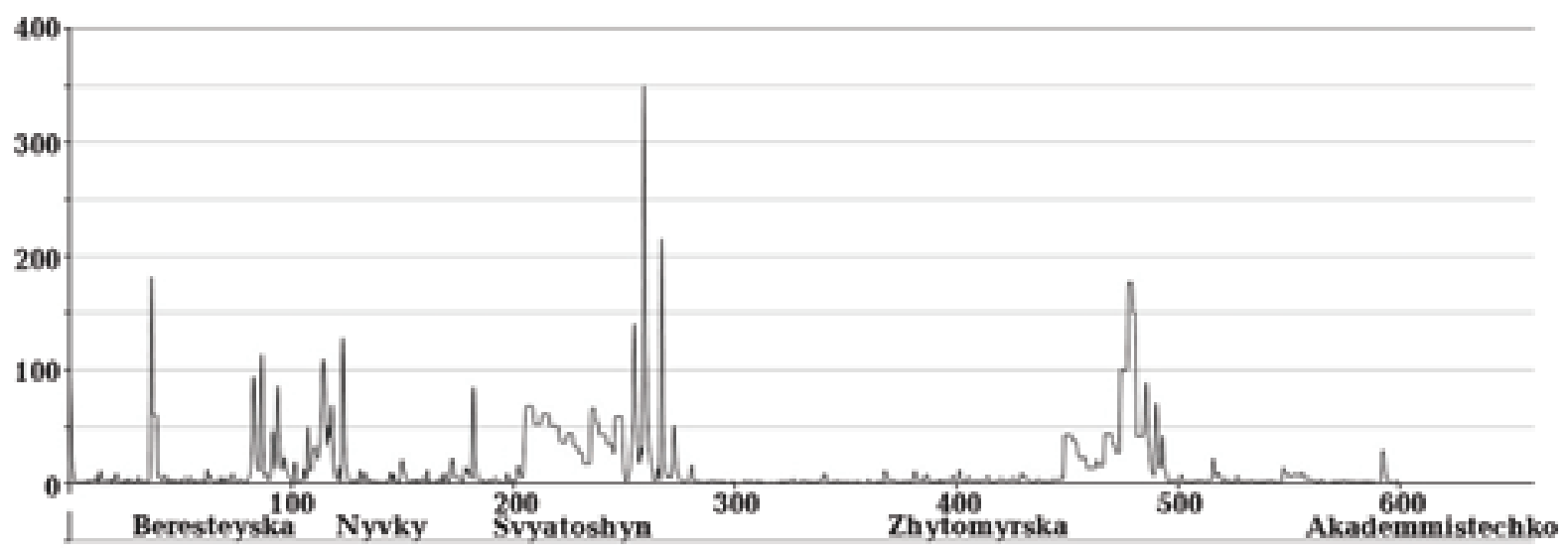

Fig. 4. Magnetic noise scalar data observed between Beresteyska and Akademmistechko metro stations. 

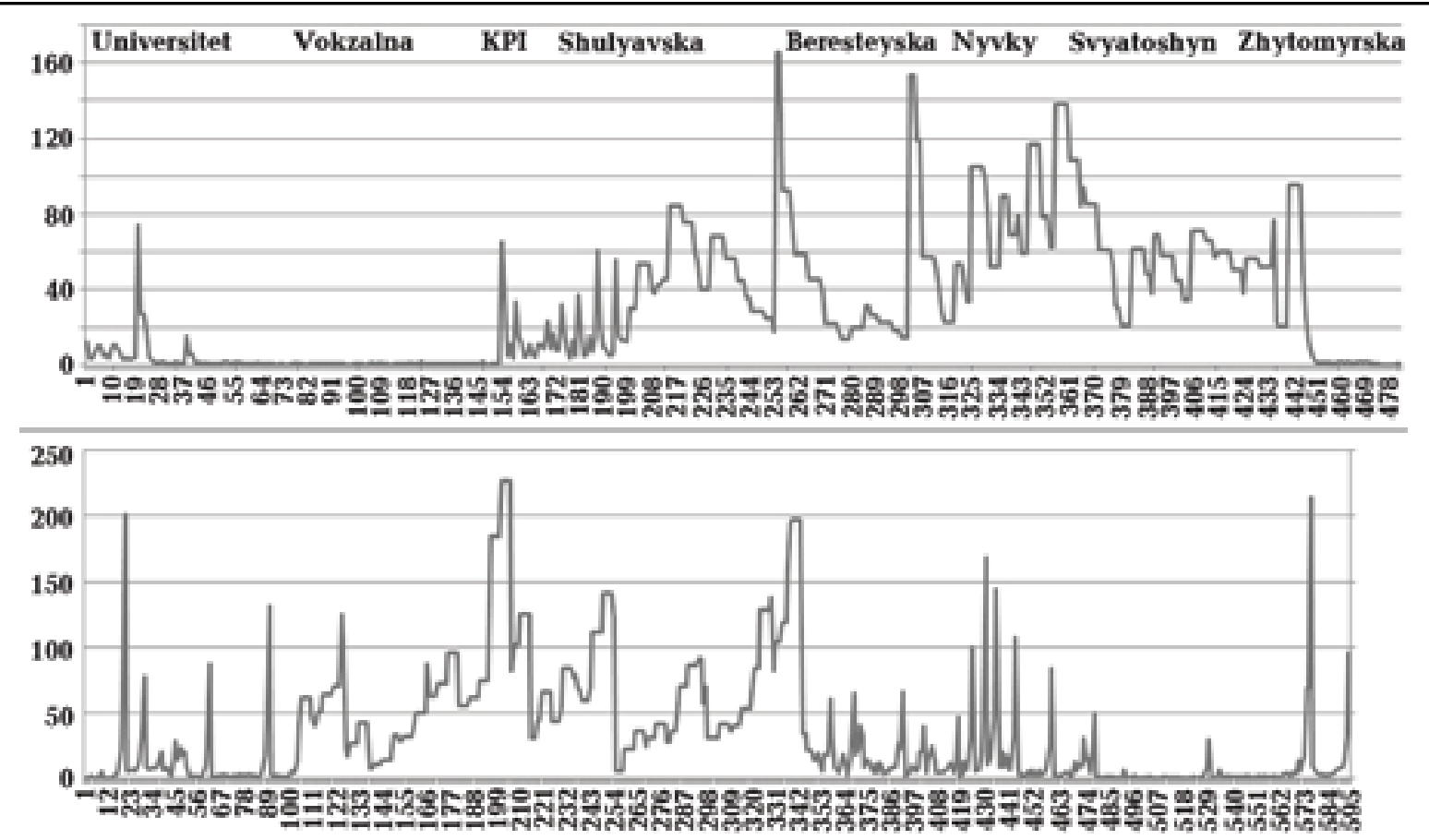

Fig. 5. Magnetic noise scalar data graphs observed between Universitet and Zhytomyrska metro stations in direct and reverse directions.

Noticeable daily rhythm of technogenic sources is proven by people operating mode and manufacturing .

We can say that people are always under influ- ence of light, it follows that technogenic magnetic perturbations can produce an effect on the living organisms as well as a strong magnetic storm.

\title{
Natural and technogenic components of megalopolis magnetic field
}

\section{(C) M. Orlyuk, A. Romenets, I. Orliuk, 2016}

\begin{abstract}
Magnetic storm influence becomes more and more interesting for people. In this article we describe measurable magnetic field data from different megalopolis regions and from the underground passenger transport by the Kyiv city example. There were five observation points evenly situated among the city, and one metro route with direct and reverse direction movement. Collected information shows general situation with magnetic noise in populous cities. Smartphones are very popular today so we have used one of them as a budget magnetometer in our research.
\end{abstract}

Key words: natural geomagnetic field, technogenic magnetic field, magnetic noise.

\section{References}

Belokrinitskiy V. S., 2009. What do mobile phone users must know? Kiev: University "Ukraine". 112 p. (in Russian).
Gvishiani A. D., Solov'yev A. A., Agayan S. M., Bogoutdinov Sh. R., Sidorov R. V., 2013. Magnetogramm algorithmic system of emission recognition. Earth's 
physical fields dynamics. Moscow: Svetoch Plyus, 297-310 (in Russian).

ICNIRP Guidelines. Guidelines for limiting exposure to time-varying electric, magnetic, and electromagnetic fields (up to $300 \mathrm{GHz}$ ), 1998. Health Physics 74 (4), 494-522.

Khramov A. V., Serpov V. Yu., Shumilov O. I., Stepanova $A$. S., 2006. The dynamic of an industrial traumatism in a zone Kursk magnetic anomaly and cosmophysical factors influence. Vestnik novykh meditsinskikh tekhnologiy (3), 174-176 (in Russian).

Korepanov V., Berkman R., Best A., Linte G.-Y., Mar'yanyuk Ya., Reda Ya., Payunpaa K., Rakhlin L., 1999. Experimental researches of ferozond magnetometers stability. Ukrainskiy metrologichnyy zhurnal(is. 3), 23-25 (in Ukrainian).

Kulikov V. Yu., Timofeeva Yu. S., 2011. Evaluating of combined geomagnetic and radiation fields influence on the osmotic resistance of human erythrocytes in vitro condition. Meditsina i obrazovanie $v$ Sibiri (4), 12-20 (in Russian).

Medvedeva O. A., Kalutskiy P. V., Besedin A. V., Medvedeva S. K., Kalutskiy A. P., 2011. The ecological and epidemiological analysis of children population intestinal infections disease of area with various level of a geomagnetic field (Kursk magnetic anomaly region). Nauchnyye vedomosti. Seriya Meditsina. Farmatsiya (10), 5-11 (in Russian).

Orlyuk M. I., Romenets A. A., Orliuk I. M., 2014. Technical low-frequency magnetic noise in Kiev. Dopovidi NAN Ukrainy (3), 110-114 (in Russian).

Orlyuk M. I., 2001. Geophysical ecology - main problems and methods of execution. Geofizicheskiy zhurnal 23 (1), 49—59 (in Ukrainian).

Orlyuk M. I., Romenets A. O., 2004. Ecological megalopolis magnetic fields (on the example Kyiv). Ekologiya i pryrodokorystuvannya (is.), 142-147 (in Ukrainian).

Orlyuk M. I., Romenets A. O., 2005. The new criterion for assessing the space-time disturbance of the Earth's magnetic field and some aspects of its use.
Geofizicheskiy zhurnal 27 (5), 744-754 (in Russian).

Pavlovich N. V., Pavlovich S. A., Galliulin Yu. I., 1991. Biomagnetic rhythms. Minsk: Publ. House "Universitetskoye", 136 p. (in Russian).

Physical factors of the working environment, 2003. Sanitary-epidemiological rules and norms. SanPiN 2.2.4.1191-03 "Electromagnetic Fields and Human Health". Moscow, 19 p. (in Russian).

Rezinkina M. M., Pelevin D. E., Dumanskiy Yu. D., Bitkin S. V., 2009. Geomagnetic field attenuation in apartment houses of different structure. Gigiena naselenykh mists (54), 209-216 (in Russian).

Romenets A. A., Orliuk I. M., 2013. Monitoring and analysis of technogenical low-frequency magnetic noise in Kyiv. Geodynamika (2), 314-316 (in Russian).

Rozov V. Yu., Pelevin D. Å., Levina S. V., 2013. Experimental research into indoor static geomagnetic field weakening phenomenon. Electrotekhnica i Electromekhanica (6), 72—76 (in Russian).

Serpov V. Yu., 2007. Influence of natural magnetic fields on human safety in areas of geophysical anomalies European part of Russia. Abstract on a dissertation of doctor of medical sciences. St-Petersburg (in Russian).

Standart of Building Biology Testing methods: SBM2008 [acting from July 2008]. Germany: Institut fur Baubiologie + Okologie. IBM. 5 p.

Travkin M. P., 1971. Life and magnetic field. Belgorod: Publisher Belgorod Pedagogical Institute. 192 p. (in Russian).

Tyagunov D. S., 2012. Spatial and temporal characteristics of the urban of technogenic magnetic noise in the frequency range $0,01-30 \mathrm{~Hz}$. Abstract dissertations of the doctor of technical sciences. Yekaterinburg, 20 p. (in Russian).

Tyagunov D. S., 2011. Technogenic electromagnetic field as an ecological factor. Ekologiya urbanizirovannykh territoriy (2), 45-50 (in Russian). 